\title{
SUBARACHNOID HAEMORRHAGE IN PREGNANCY WITH HYPERTENSION DUE TO UNILATERAL PYELONEPHRITIS
}

\author{
B. Ashworth, M.B. (St. And.), M.R.C.P., M.R.C.P.E. \\ Medical Registrar, Crumpsall Hospital, Manchester 8
}

THE experimental work of Goldblatt (1934) showed that in some animal species partial occlusion of one renal artery resulted in sustained hypertension, and that removal of the ischæmic kidney might restore the blood pressure to its original level. The first practical application of this work was reported by Butler in 1937 from the Boston Children's Hospital. Two patients with hypertension due to unilateral pyelonephritis were treated by removing the diseased kidney and in both the blood pressure returned to normal (quoted by Homer Smith 1956). Since that time difficulties have arisen over the selection of cases for nephrectomy, particularly where the affected kidney still retains some function, and there is doubt about the integrity of the other kidney.

\section{Case Report}

The patient was a married woman aged 23 years. She was admitted to Crumpsall Hospital in September, 1959, and had been in good health until two days previously. She then complained of a severe generalised headache of sudden onset associated with dizziness and vomiting. On the following day the headache was still present and she became drowsy and confused. Last menstrual period August 25, 1959.

Previous history. Operation for intestinal obstruction in infancy. Delivered of a normal child in February, 1959. Blood pressure during the pregnancy was $130 / 75$ to $135 / 80 \mathrm{~mm}$. Hg. History of headache on waking during the three months before admission.

\section{Examination}

Patient drowsy and slightly confused. Blood pressure 2 ro/145 mm. Hg. C.V.S.: Pulse regular. Heart not clinically enlarged. Heart sounds normal. No œdema. Chest: normal. Abdomen: A mass was easily felt in the right loin. It was smooth, firm, not tender and moved downwards on inspiration. C.N.S.: Pupils normal. Retina: arteries normal, veins engorged; no hæmorrhage or exudate; right optic disc normal, left optic disc showed early papillœedema. Visual fields and eye movements satisfactory. Slight neck stiffness. No other abnormality.

\section{Investigations}

Lumbar puncture: Resting pressure $190 \mathrm{~mm}$. water; fluid bloodstained and supernatant fluid xanthochromic. Protein $220 \mathrm{mg}$. $/ 100 \mathrm{ml}$. Blood urea $38 \mathrm{mg} . / 100 \mathrm{ml}$. Serum K 4 mEq./l. Hæmoglobin I 5.4 g./ $100 \mathrm{ml}$., white cell count $8,000 / \mathrm{cu}$. $\mathrm{mm}$. E.S.R. $3 \mathrm{~mm}$. $/ \mathrm{hr}$. (Westergren). Urine: $\frac{1}{2} \mathrm{gm}$. of protein daily, deposit contained excess of polymorph cells and growth of coliform organisms obtained on culture. Glucose tolerance test normal. Catechol amine excretion normal. X-rays of chest, skull, and abdomen normal. Electrocardiograph showed changes indicative of left ventricular hyper- trophy. Intravenous pyelogram: Normal appearances on the left side. No excretion of dye on the right side. Right retrograde pyelogram: The right ureter filled with dye but the renal pelvis could not be demonstrated. Phentolamine test: The steady resting blood pressure was $170 / 110 \mathrm{~mm}$. $\mathrm{Hg}$. After giving $5 \mathrm{mg}$. of phentolamine intravenously the pressure fell to $160 / 90 \mathrm{~mm}$. $\mathrm{Hg}$. in three minutes. The blood pressure returned to the original level after ro minutes. This was interpreted as a negative result.

\section{Progress}

There was a steady improvement in her general condition after admission. At the end of a week the headache was much less severe and the patient quite rational. The blood pressure varied between $190 / 135$ and $160 / 110 \mathrm{~mm}$. Hg.

\section{Operation (Mr. Arnold Ashworth), October, 1959}

An intravenous drip was started before the operation in order that phentolamine or noradrenaline could be given if the need arose. The kidney was exposed by a curved incision through the bed of the 12 th rib. The kidney was found to be grossly hydronephrotic and tightly distended. The renal pelvis was very large and the upper part of the ureter was kinked and adherent to the pelvis and there appeared to be a constriction at the pelvi-ureteric junction. A nephrectomy was carried out without difficulty.

Pathological Report (Dr. J. Davson)

The kidney measured $10 \times 4 \mathrm{~cm}$. The pelvis and calyces were much dilated. The junction of the ureter and pelvis was stenosed and at this point the ureter was sharply kinked. The kidney showed thinning of the cortex.

Microscopically the kidney parenchyma showed diffuse fibrosis and round-celled infiltration with marked atrophy of the tubules and periglomerular fibrosis. Section of the kink at the pelvi-ureteric junction showed no obvious cause for this. Diagnosis: Hydronephrosis with diffuse chronic pyelonephritis due to kinked ureter.

\section{Follow Up}

The blood pressure has remained normal for a yearI $30 / 80 \mathrm{~mm}$. Hg. being the highest level recorded.

There has been no further headache. The urine is free from protein. Six months after the operation the patient was delivered of a full time normal infant.

\section{Discussion \\ Presenting Features}

The presenting feature of subarachnoid hæmorrhage is presumably related to the hypertension. It is well known that there is an increased incidence of subarachnoid hæmorrhage in patients with hypertension. In these it is sometimes 
possible to demonstrate an intracranial aneurysm. Satisfactory carotid angiograms in this patient failed to show any abnormality. It remains possible, of course, that an aneurysm was present which did not fill adequately with dye, contained thrombus, or was situated on the basilar arterial system. In an appreciable proportion of normotensive patients (31.6\% according to Bull (1958)) investigated after subarachnoid hæmorrhage no vascular abnormality can be demonstrated by carotid angiography.

It seems reasonable to suppose that the hypertension was a causal factor in this patient's subarachnoid hæmorrhage. Such an incident is a very rare presenting feature in unilateral renal disease. Its occurrence during pregnancy has not previously been reported.

\section{Diagnosis}

The alternative diagnosis of phæochromocytoma was considered. Compression of the mass in the right loin did not produce any alteration in the blood pressure. The phentolamine test was negative. The catechol amine excretion was normal but this has also been reported in a case in which phæochromocytoma was later proved (Litchfield and Peart, 1956). Phæochromocytoma arising within the renal capsule has been described (Pengelly, 1959). In one reported case an abnormal kidney was thought to be the cause of hypertension but a phæochromocytoma was also present (Crowther, 195I). The possibility of phæochromocytoma could not be entirely ruled out before operation.

\section{The Pathological Disturbance in the Kidney}

The hydronephrosis and infection of the right kidney was presumably consequent upon partial obstruction of flow in the right ureter. The kink in the ureter was probably a congenital abnormality. There was no evidence of an aberrant renal artery.

\section{The Blood Pressure and Effect of Nephrectomy}

It is known that the blood pressure was below $135 / 80 \mathrm{~mm}$. Hg. at the time of her first pregnancy which ended seven months before the subarach- noid hæmorrhage. During the period in hospital before operation the blood pressure fluctuated between 190/135 and 160/1 10 mm. Hg. After removal of the diseased kidney the blood pressure quickly settled to $120 / 80 \mathrm{~mm}$. $\mathrm{Hg}$. and has remained below $130 / 80 \mathrm{~mm}$. $\mathrm{Hg}$. for a year.

Several authorities have defined criteria of cure of hypertension in this condition. Homer Smith (1956) required a follow up for a minimum of one year and a blood pressure below $140 / 90 \mathrm{~mm}$. $\mathrm{Hg}$. This has met with general agreement (Thompson 1957; Yates-Bell, 1959).

The results of nephrectomy in unilateral renal disease cannot be accurately predicted. (In this patient there was no difficulty in making a decision to carry out nephrectomy. She clearly had a large, non-functioning, and infected kidney which required treatment in its own right quite apart from the hypertension.) Homer Smith (1956) reviewed the reports of 575 nephrectomies carried out in hypertensive patients and found that $26 \%$ had a blood pressure of $140 / 90 \mathrm{~mm}$. Hg. or less after one year. Yates-Bell (1959) reported 66 cases and claimed a cure-rate of $45 \cdot 5 \%$. He found that the results were better in young patients and that patients over 50 rarely benefit unless the hypertension is recent.

This case again serves to emphasise the importance of searching for an underlying cause when hypertension is found in young people.

\section{Summary}

I. A case of subarachnoid hæmorrhage in a woman of 23 years associated with severe hypertension is reported.

2. An infected, hydronephrotic kidney was removed. The blood pressure returned to normal and has remained satisfactory for a year. The patient was pregnant and was delivered of a normal child six months after operation.

3. The importance of recognising unilateral renal disease as a cause of hypertension is stressed.

I am grateful to Dr. G. E. Smyth and Mr. Arnold Ashwortl for permission to publish this report, and Dr. J. Davson for the pathological report. I should also like to thank Dr. Smyth and Dr. Davson for helpful discussion and criticism.

\section{REFERENCES}

Bull, J. W. D. (1958): Radiological Investigation in Cases of Cerebrovascular Disease, Brit. med. $\mathcal{F}$., i, 795 .

Crowther, K. V. (195 I): Two Cases of Phæochromocytoma, Brit. med. F., i, 445.

Goldelat, H., et al. (1934): Proceedings of Conference on Basic Mechanisms of Arterial Hypertension (r958), quoted in Goldblatt, H. (1958), Circulation, r7, 641.

Litchfield, J. W., and Peart, W. S. (1956): Phæochromocytoma with Normal Excretion of Adrenaline and Noradrenaline, Lancet, ii, 1283 .

Pengflly, C. D. R. (1959): Phæochromocytoma within the Renal Capsule, Brit. med. F., ii, 477.

SмIтн, H. (r956): Unilateral Nephrectomy in Hypertensive Disease, $\mathcal{F}$. Urol., 76, 685.

Thompson, G. J. (1957): Results of Nephrectomy in Hypertensive Patients, $\mathcal{F}$. Urol., 77, 358.

Yates-Bell, J. G. (1959): Nephrectomy in Cases of Hypertension, Brit. med. $\mathcal{F}$., ii, I371. 